\title{
Jonathan Haidt, Prawy umyst. Dlaczego dobrych ludzi dzieli re- ligia i polityka?, Wydawnictwo Smak Słowa, Sopot 2014, ss. 512
}

Przedstawiana czytelnikom „Rocznika Andragogicznego” publikacja osiągnęła w momencie pojawienia się na rodzimym rynku wydawniczym szczególny status, który polegał na wyjątkowym zainteresowaniu mediów. Przecież jest raczej sytuacją niespotykaną, że tak duża liczba dzienników i tygodników, w tym m.in. „Polityka”, „Newsweek”, „Rzeczpospolita”, „Gazeta Wyborcza”, „Przegląd” i „Gość Niedzielny”, wyraża nie tylko zainteresowanie nową książką, ale umieszcza obszerne recenzje i komentarze odnoszące się do jej treści. Jeżeli dodamy, że podobnie zareagowały rozgłośnie radiowe, na czele z opiniotwórczymi programami Polskiego Radia, to mamy do czynienia $\mathrm{z}$ interesującym zjawiskiem. Warto zatem zastanowić się nad tym, dlaczego właśnie ta publikacja, autorstwa amerykańskiego naukowca, wywołała tak duże zainteresowanie, którego nie sposób sprowadzić jedynie do skutecznej akcji promocyjnej. Podobne zdarzenia miały miejsce zarówno w Stanach Zjednoczonych, jak i w Wielkiej Brytanii, gdzie pojawienie się publikacji wywołało dyskusję w środowiskach naukowych i wzbudziło zainteresowanie czytelników, niezwiązanych ze środowiskami akademickimi. Kim jest zatem autor? Jonathan Haidt jest psychologiem, profesorem Stanowego Uniwersytetu w Wirginii. Jak sam o sobie mówi, jest białym przedstawicielem klasy średniej, jajogłowym akademikiem i myślicielem o wysokiej pozycji na anglosaskim rynku idei. Kilkadziesiąt ostatnich lat jego aktywności naukowej skoncentrowane było na badaniu psychologii moralności, przy jednoczesnym holistycznym jej postrzeganiu, z uwzględnieniem perspektywy antropologicznej i filozoficznej. Autor, odnosząc się do wybranego przez siebie tytułu książki, jednoznacznie zauważa: „Mogłem zatytułować tę książkę Umysł moralny, aby wyrazić ideę, że ludzki umysł jest stworzony do tego, by zajmować się moralnością. Zdecydowałem się jednak na tytuł Prawy umysł, 
który zawiera w sobie myśl, że ludzki umysł jest z natury nie tylko moralny, ale także skłonny do moralizowania, krytykowania i oceniania" (s. 4).

Powyższy wybór trafnie legitymizują tytuły kolejnych trzech części publikacji: Intuicje pojawiajq się pierwsze, strategiczne rozumowanie - drugie, Moralność to coś więcej niż tylko krzywda i sprawiedliwość oraz Moralność wiq̨że i zaślepia. Cześć pierwsza to przede wszystkim interesujący opis genezy postrzegania moralności przez nauki społeczne $z$ uwzględnieniem ogromnego dorobku intelektualnego naszej cywilizacji oraz z zaakcentowaniem koncepcji Platona, Immanuela Kanta, Thomasa Jeffersona, Davida Hume'a, Jeana Piageta, Lawrence’a Kohlberga, a także antropologów i psychologów, takich jak Richard Shweder i Elliot Turiel. Otwartość autora na dorobek naukowy innych dziedzin, a co za tym idzie - inspirowanie się doświadczeniami i osiągnięciami przedstawicieli innych dyscyplin we własnych pracach, ilustruje swego rodzaju stygmat, który staje się powinnością współczesnego badacza. Autor umiejętnie uzasadnia potrzebę takiego postępowania, opisując go próbami odnalezienia swojego Kamienia z Rosetty, który w przeszłości umożliwił przecież odczytanie egipskich hieroglifów. Ale pierwsza część to nie tylko błyskotliwe odniesienie się autora do postrzegania moralności na przestrzeni lat; to również przedstawienie konkretnych wyników badań, które analizowane teorie potwierdzają lub obalają.

W drugiej części autor umiejętnie nawiązując do swoich doświadczeń naukowych, przez przedstawienie wyników badań, analizując teorię sześciu fundamentów moralnych, odnosząc się bezpośrednio do rzeczywistości społecznej w Stanach Zjednoczonych, także w wymiarze politycznym.

W części trzeciej publikacji Jonathan Haidt m.in. stara się odpowiedzieć na pytanie, dlaczego jesteśmy „grupolubni” i przedstawia dorobek badaczy nad zbiorowościami. Tytuł dwunastego rozdziału Czy nie moglibyśmy się nie zgadzać bardziej konstruktywnie? stanowi swego rodzaju konkluzję dla całej pracy i, nie jest potwierdzeniem naiwności autora, ale zaplanowaną intelektualnie i uzasadnioną konsekwencją wcześniejszych rozważań. Autor potrafi odnosić się krytycznie także do zdawałoby się ugruntowanych przekonań własnego środowiska, a jego intuicje co do funkcjonowania świata związanego z naszymi wyborami politycznymi są na tyle uniwersalne, że mogą inspirować refleksję dotyczącą innych przestrzeni aktywności współczesnego człowieka.

Można się nie zgodzić z konkluzją Jonathana Haidta zawartą w podsumowaniu, dotyczącą natury naszych wyborów moralnych, ale nie sposób przejść obojętnie obok sformułowania kończącego książkę: „Moralność wiąże i zaślepia. Wiąże nas w ideologiczne drużyny, które zwalczają się tak za- 
ciekle, jak gdyby losy świata zależały od tego czy nasza drużyna wyjdzie zwycięsko z każdej bitwy. Czyni nas ślepymi na fakt, że w skład z każdej z drużyn wchodzą dobrzy ludzie, którzy mają coś ważnego do powiedzenia" (s. 25).

Erudycja autora jako pisarza, ale przede wszystkim naukowca o ogromnej wiedzy i doświadczeniu, skłania do wyrażenia opinii, że zdecydowanie warto zapoznać się z recenzowaną publikacją. Może także po to, żeby rozumieć nie tylko samotnych i systemowo wykluczonych, ale przede wszystkim tych z naszych środowisk rodzinnych, koleżeńskich, sąsiedzkich i akademickich, którzy często reprezentują poglądy i punkty widzenia bardzo odbiegające od naszych.

Michał Szykut 